\title{
Non-Specific Low Back Pain In Elderly And The Effects Of Myofascial Release Technique Combined With Core Stabilization Exercise: Not Just Muscles [Letter]
}

This article was published in the following Dove Press journal:

Clinical Interventions in Aging

\section{Bruno Bordoni (D)}

Department of Cardiology, Foundation Don Carlo Gnocchi IRCCS, Institute of Hospitalization and Care with Scientific, Milan, Italy
Correspondence: Bruno Bordoni Department of Cardiology, Foundation Don Carlo Gnocchi IRCCS, Institute of Hospitalization and Care with Scientific, S Maria Nascente, Via Capecelatro 66, Milan 20100, Italy

Tel +39023496300617

Email bordonibruno@hotmail.com

\section{Dear editor}

I would first like to congratulate Ozsoy et al on the publication of their research article on treatment in the elderly with non-specific low back pain (NSLBP) and the effects of myofascial release technique. ${ }^{1}$ The topic is interesting and clinically relevant, because back problems increase with ageing, but I would like to clarify some of the concepts expressed in the article.

The causes that determine low back pain (LBP) are different and it is not possible to carry out this pathology to a dysfunction of a single tissue (fascia) and of a muscular structure that could (theoretically) influence the back. In the introduction of the text it is possible to read: "Because of the changes in fascia structures, dysfunction of deep muscles of back and trunk is common in chronic LBP. Injuries of the lower back are mostly caused by the superficial back line (SBL)". And yet we can read: "Chronic LBP is caused by deep muscle dysfunctions and altered fascia structures." Currently, we have no absolute evidence on the influence of muscle chain theory and health status, as well as the causes that determine LBP in the elderly have different origins. For example, in $41 \%$ of patients with NSLBP, the pain is caused by the presence of iliac crest pain syndrome (ICPS), an alteration of tendon tissue on the bone area of the iliac crest (tendinopathy) of the erector spinae muscle. ${ }^{2}$

In the introduction section it is written: “ $\ldots$ by increased activation in the superficial muscles (such as the erector spinae) in patients with LBP". ${ }^{1}$ The erector spinae muscles are made up of different muscles (spinalis, longissimus thoracis, and iliocostalis muscles) and are not superficial muscles. ${ }^{3}$ For their identification, for example for the erector spinae plane (ESP) block, ultrasound is used, as in cases of postoperative pain in thoracic surgery or in cases of chronic thoracic neuropathic pain. ${ }^{3}$

The core stability exercise described by Ozsoy et al is cited as: " ... core stability exercise is more effective than general exercise". ${ }^{1}$ In reality, it is only partially true, because a review study highlights the effectiveness of the exercise but emphasizes the equality of the presence of long-term pain between the usual exercises and the core stability. ${ }^{4}$

NSLBP does not depend only on muscular alterations, but also on neurological alterations and neuropathic, central (sensitization) or peripheral (allodynia) 
components, particularly in females. ${ }^{5}$ The role of the diaphragm muscle in lumbar stabilization has not been taken into consideration, as well as a possible assessment of its position and movement was not considered. In the presence of NSLBP, there are alterations of the disc (annulus fibrosus fissures) and of the grosser morphological alterations of the vertebrae (not symptomatic). In the study by Ozsoy et al, ${ }^{1}$ the latter information was not taken into account, leading to questionable results.

To conclude, in the conclusions section the placebo effect of the treatment was not taken into consideration, which could induce false results.

\section{Disclosure}

The author reports no conflicts of interest in this communication.

\section{References}

1. Ozsoy G, Ilcin N, Ozsoy I, et al. The effects of myofascial release technique combined with core stabilization exercise in elderly with non-specific low back pain: a randomized controlled, single-blind study. Clin Interv Aging. 2019;14:1729-1740. doi:10.2147/CIA. S223905

2. Todorov P, Nestorova R, Batalov A. The sonoanatomy of lumbar erector spinae and its iliac attachment - the potential substrate of the iliac crest pain syndrome, an ultrasound study in healthy subjects. $J$ Ultrason. 2018;18(72):16-21. doi:10.15557/JoU.2018.0003

3. Kot P, Rodriguez P, Granell M, et al. The erector spinae plane block: a narrative review. Korean $J$ Anesthesiol. 2019;72(3):209-220. doi:10.4097/kja.d.19.00012

4. Wang XQ, Zheng JJ, Yu ZW, et al. A meta-analysis of core stability exercise versus general exercise for chronic low back pain. PLoS One. 2012;7(12):e52082. doi:10.1371/journal.pone.0052082

5. Vagaska E, Litavcova A, Srotova I, et al. Do lumbar magnetic resonance imaging changes predict neuropathic pain in patients with chronic non-specific low back pain? Medicine (Baltimore). 2019;98 (17):e15377. doi:10.1097/MD.0000000000015377

Dove Medical Press encourages responsible, free and frank academic debate. The content of the Clinical Interventions in Aging 'letters to the editor' section does not necessarily represent the views of Dove Medical Press, its officers, agents, employees, related entities or the Clinical Interventions in Aging editors. While all reasonable steps have been taken to confirm the content of each letter, Dove Medical Press accepts no liability in respect of the content of any letter, nor is it responsible for the content and accuracy of any letter to the editor.

\section{Publish your work in this journal}

Clinical Interventions in Aging is an international, peer-reviewed journal focusing on evidence-based reports on the value or lack thereof of treatments intended to prevent or delay the onset of maladaptive correlates of aging in human beings. This journal is indexed on PubMed Central, MedLine, CAS, Scopus and the Elsevier
Bibliographic databases. The manuscript management system is completely online and includes a very quick and fair peer-review system, which is all easy to use. Visit http://www.dovepress.com/ testimonials.php to read real quotes from published authors. 